\title{
The Problem of Bankruptcy of Business Entities as a Consequence of the COVID-19 Pandemic
}

\author{
Submitted 06/06/20, $1^{\text {st }}$ revision 21/07/20, $2^{\text {nd }}$ revision 16/08/20, accepted 15/09/20 \\ Tatyana A. Skvortsova ${ }^{1}$, Tatyana A. Pasikova ${ }^{2}$, Liliya N. Vereshchagina ${ }^{3}$, \\ Alexsei N. Pozdnishov ${ }^{4}$, Anna V. Sukhovenko ${ }^{5}$
}

\begin{abstract}
:
Purpose: The purpose of the article is to perform an economic and legal analysis of the problem of insolvency (bankruptcy) of business entities in conditions of the COVID-19 pandemic.

Design/Methodology/Approach: Utilizing general scientific (systemic, dialectical and sociological) and specific scientific (normative-logical, comparative-legal, technical-legal, legal statistics) methods of researching economic and legal phenomena, the authors analyzed the concept and basic prerequisites for insolvency (bankruptcy) of entrepreneurial structures, the measures for the introduction of a moratorium on the bankruptcy of business entities undertaken by the Governments of Russia and Germany are considered and evaluated.
\end{abstract}

Findings: As a result of the study, the authors concluded that during a pandemic, the risk factor for bankruptcy of business entities significantly increases and it is necessary to take measures to prevent the bankruptcy of business entities. The introduction of a moratorium on the bankruptcy of economic entities served as such measures in Russia and Germany. For these purposes, an appropriate regulatory and legal framework was created, providing for a ban on the introduction of bankruptcy procedures of certain economic entities.

Practical Implications: The authors proposed introducing extra measures to prevent the bankruptcy of business entities in Russia in connection with the COVID-19 pandemic. In particular, it was proposed to borrow foreign experience and introduce a moratorium on the obligation to file an application by a debtor - a business entity to declare it a bankrupt, to fix a regulatory moratorium on filing applications to the arbitration court for the recognition of business entities as bankrupt by tax authorities.

Originality/Value: State policy to prevent the bankruptcy of business entities in the sectors most affected by the COVID-19 restrictions significantly affects the number of bankruptcies of business entities due to the pandemic. In this regard, measures to prevent mass

\footnotetext{
${ }^{1}$ Rostov State University of Economics, Rostov-on-Don, Russian Federation, tas242@yandex.ru

${ }^{2}$ Rostov branch of the Rostov state University of justice, Rostov-on-Don, Russian Federation, tatyana-plotko@yandex.ru

${ }^{3}$ Don State Technical University, Rostov-on-Don, Russian Federation, vereshagina.lil@mail.ru

${ }^{4}$ Rostov State University of Economics, Rostov-on-Don, Russian Federation, profepifanova@gmail.com

${ }^{5}$ Rostov State University of Economics, Rostov-on-Don, Russian Federation, kafedra37@bk.com
} 
bankruptcy of entrepreneurs are an important factor in maintaining the stability of the state's economy.

Keywords: Business entities, insolvency (bankruptcy), financial stability, pandemic, moratorium on bankruptcy.

JEL codes: E60, K 15, L26.

Paper type: Research article.

\section{Introduction}

In a market economy, the bankruptcy phenomenon plays a very important role. Bankruptcy is considered one of the most important legal procedures, aimed at stabilizing the economic activity and ensurng trust between its participants. Bankruptcy procedures provide a debtor in a difficult financial situation with the opportunity to restore his solvency, and if it is impossible to restore it, such procedures allow ensuring the fullest satisfaction of the interests of creditors (Zalogin, 2010). The institution of bankruptcy in the modern world is a market instrument for capital redistribution. The conditions of the business environment are formed under the influence of government regulation and the market mechanism, (Epifanova et al., 2015). Insolvency (bankruptcy) becomes the consequence of tough market competition and ineffective capital management (Sergienko, 2015).

The bankruptcy of business entities is a natural process of clearing the market from non-competitive structures (Turbanov, 2006) because in the case of insolvency (bankruptcy) of a commercial organization, the legislation establishes the dissolution of the latter as a legal consequence (Skvortsova et al., 2018). It should also be pointed out that the institution of bankruptcy also performs other functions that provide for the possible rehabilitation and restoration of the solvency of such ineffective economic entities; protection of creditors' rights in the course of economic activity and in the process of bankruptcy (Glugovskaya and Skvortsova, 2018).

Some authors characterize bankruptcy as the revival of the economy, business, and production. From this point of view, bankruptcy proceedings are not only an inevitable reality for most enterprises, but also an obvious boon. Bankruptcy is a means of protection from creditors, an opportunity to get deferred payment of debts, restructure and renew a business. The goal of bankruptcy is the complete preservation of the debtor enterprise (Aloev et al., 2015).

But in the Russian Federation, statistics indicates that the application of bankruptcy procedures entails, in the overwhelming majority, the dissolution of a business entity. According to research in 2018, the share of successful rehabilitation procedures was only $0.2 \%$. $70 \%$ of debtors-legal entities entered bankruptcy 
procedures already without property. Assets in bankruptcy are sold five times cheaper than market value on average, and creditors receive no more than $4-5 \%$ of debt as a result. Thus, the institution of bankruptcy in Russia performs a liquidation function; there is practically no business recovery.

An increase in the number of bankruptcies of business entities may indicate an unfavorable external environment for doing business. So, during the COVID-19 pandemic, there is an economic recession around the world, enterprises cannot fully and effectively function (Grima et al., 2020; Khan et al., 2020). In this regard, the prerequisites for the insolvency of business entities have sharply increased. An avalanche-like termination of business as a result of bankruptcy can lead to disruptions in the functioning of the economic system. Therefore, in this case, state intervention is required, the application of regulatory measures of state influence, taking into account the interests of business (Shatkovskaya and Epifanova, 2016). During a pandemic, it is necessary to develop adequate support measures for business entities aimed at preventing massive bankruptcies.

\section{The Concept and Prerequisites of Insolvency (Bankruptcy) of Business Entities}

The current Russian legislation contains the following concept of bankruptcy: insolvency (bankruptcy) - the inability of the debtor recognized by the arbitration court to fully satisfy the claims of creditors for monetary obligations, for the payment of severance pay and (or) for remuneration of persons who work or worked under an employment contract, and (or) fulfill the obligation to pay mandatory payments (Art. 2 of the Federal Law of October 26, 2002 No. 127-FZ (as amended on July 13, 2020) "On Insolvency (Bankruptcy)").

The following prerequisites for the bankruptcy of business entities could be distinguished: violation of financial stability and stable insolvency.

In our opinion, special attention should be paid to the financial stability of organizations. In the economic literature, there is no clear concept of what "financial stability" is, but as a rule, it means the final indicator that characterizes the financial condition of an economic entity as a whole (Kovan and Kochetkov, 2009). Note that the concept of "financial stability" of an organization is multifaceted, it is more multifaceted than the concepts of "solvency" and "creditworthiness", since it includes an assessment of various aspects of the organization's activities.

The purpose of determining the financial stability of an economic entity is the timely identification and elimination of shortcomings in the financial activities of the enterprise, as well as in the structure of assets and liabilities already established at this enterprise (Milyutina, 2017). In order to achieve this goal, it is necessary to complete certain tasks including determining the degree of financial stability, 
identifying the problem of violation of financial stability, developing measures aimed at increasing financial stability.

There are four types of financial stability:

1. Absolute financial stability - characterized by a high level of solvency;

2. Normal financial stability - characterized by normal solvency and rational use of borrowed funds;

3. Unstable financial condition - characterized by a violation of normal solvency as well as attracting additional sources of funding;

4. Crisis financial condition - characterized by the lack of funding sources, the company is on the verge of bankruptcy (Bocharov, 2018).

The essence of financial stability lies in stable solvency due to a sufficient share of equity capital, which allows you to successfully manage financial stability, and also makes the organization independent from creditors (Korovaeva, 2011). This in turn reduces the possibility of a legal entity going bankrupt. Financial stability directly depends on the results of the enterprise. So, if the enterprise fulfills the norms of production and financial plans, then such an enterprise is the most stable, in comparison with an enterprise not fulfilling these plans in full or in part. Therefore, during a pandemic and the introduction of various restrictions on the activities of enterprises, the financial stability of economic entities decreases sharply due to a significant decrease in the volume of production and sale of goods.

Also, a break in financial stability could be observed in connection with the attraction of credit and borrowed funds by the organization, the amount of which exceeds its existing assets. If this situation arises, the organization cannot completely fulfill its obligations to repay the loan, which multiplies the risk of bankruptcy. Such risks increase significantly during a pandemic and imposed restrictions.

Another reason for bankruptcy is insolvency, by which it is customary to understand the inability of an organization to fulfill its obligations to pay payments in a timely manner and in full.

Russian bankruptcy legislation identifies insolvency as the main sign of insolvency (bankruptcy) of an organization. According to Art. 3 of the Federal Law of October 26, 2002 No. 127-FZ (as amended on July 13, 2020) "On insolvency (bankruptcy)", a legal entity is considered incapable of satisfying creditors' claims for monetary obligations, on the payment of severance benefits and (or) on remuneration of persons working under an employment contract, and (or) fulfill the obligation to pay mandatory payments if the corresponding obligations and (or) the obligation has not been fulfilled by him within three months from the date when they were to be performed. In this case, the minimum amount of creditors' claims against a legal entity is set at 300,000 rubles (as a general rule). In relation to individual entrepreneurs, the legislation also established the insolvency criterion as the basis for 
declaring him bankrupt. According to Art. 214 of the Federal Law of October 26, 2002 No. 127-FZ (as amended on July 13, 2020) "On insolvency (bankruptcy)", the basis for declaring an individual entrepreneur bankrupt is his inability to satisfy the claims of creditors for monetary obligations and (or) fulfill the obligation to pay obligatory payments. Moreover, according to Art. 213.2 of the said Law, an application for declaring him bankrupt is accepted by the arbitration court, provided that the requirements are at least 500,000 rubles and the specified requirements have not been fulfilled within three months from the date when they should be fulfilled.

Thus, for all business entities, a period of three months is set for the fulfillment of obligations to creditors. The debtor could then be declared insolvent. Accordingly, during a pandemic, when a regime of restrictions on the activities of entrepreneurs and a regime of self-isolation for citizens is introduced for a period of several months, the prerequisites for the bankruptcy of economic entities with a high degree of probability and those who will not be able to fulfill their obligations to creditors in such a short period, sharply increase. Accordingly, it becomes necessary to introduce measures to prevent this situation. The Russian Federation has taken the path of introducing a moratorium on bankruptcies of certain categories of debtors.

\section{Bankruptcy Statistics of Business Entities in the Russian Federation and the Introduction of a Moratorium on Bankruptcy}

Let's consider the statistics of bankruptcies of business entities in Russia. Figure 1 shows the dynamics of the number of bankruptcies in the Russian economy, and Figure 2 presents data reflecting the actual number of bankruptcies in the economy.

Figure 1. The number of bankruptcies in the Russian economy (Forecats, 2020)

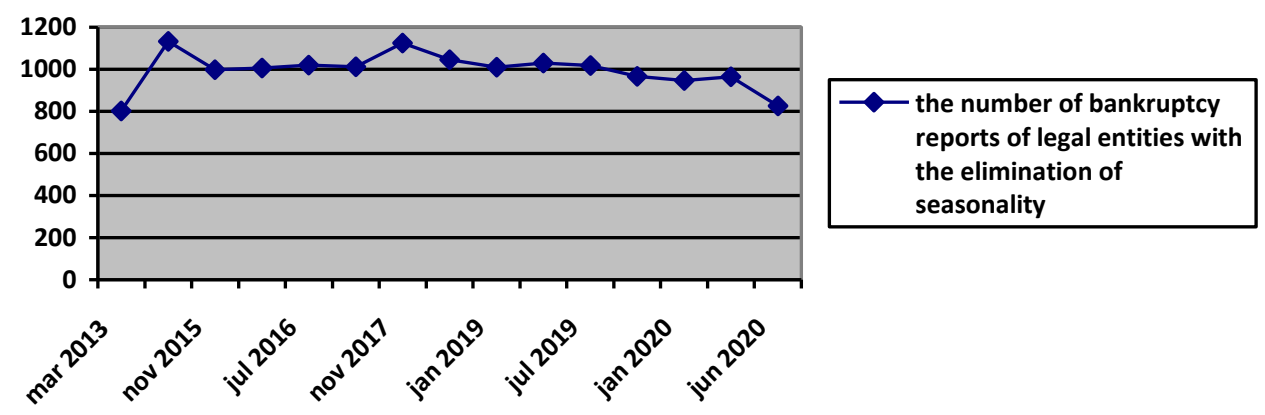

Source: Own study.

Let's analyze statistical data, including those based on the method of legal statistics (Shatkovskaya et al., 2019). Based on the data presented, it could be concluded that the number of bankruptcies of legal entities before the pandemic fluctuated. Until 2018, there was a general trend towards an increase in the number of bankruptcies; 
in 2019, there was a slight decrease in this number. During the period of imposition of restrictions and self-isolation due to the threat of the spread of the coronavirus infection COVID 19, the number of bankruptcies decreased. This is due, in our opinion, to the introduction of a moratorium on bankruptcy in Russia.

Figure 2. The number of bankruptcies in the Russian economy (fact) (Forecats, 2020)

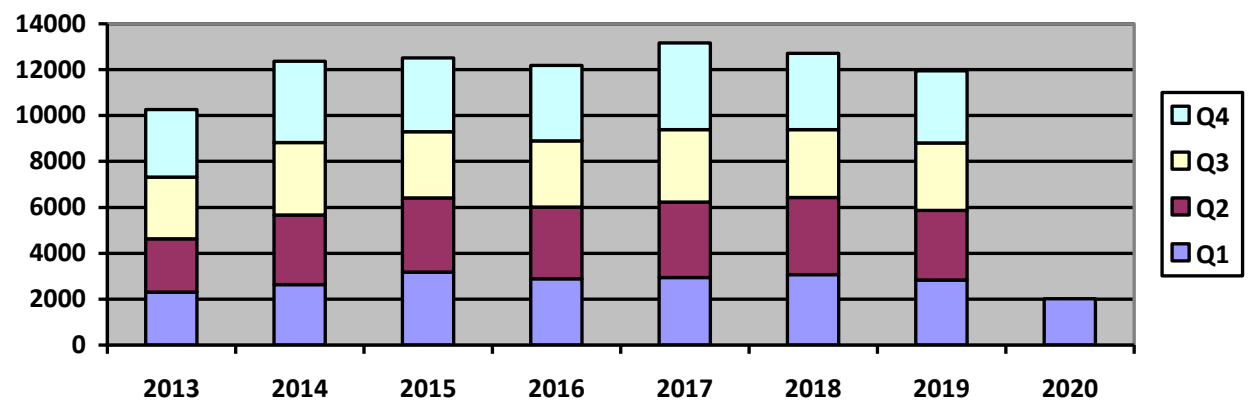

Source: Own study.

The possibility of introducing a moratorium on bankruptcy was consolidated by introducing Article 19.1 into the Federal Law "On Insolvency (Bankruptcy)" entitled "Moratorium on initiating bankruptcy proceedings". This amendment authorized the Government to introduce and subsequently extend the moratorium on the initiation of bankruptcy proceedings. In order to exercise this power, the Government should adopt an appropriate resolution.

By Decree of the Government of the Russian Federation of 03.04.2020 No. 428 (as revised on 22.05.2020) "On the introduction of a moratorium on the initiation of bankruptcy proceedings at the request of creditors in respect of individual debtors", on the basis of this article, a moratorium was introduced on the initiation of bankruptcy proceedings at the request of creditors in in relation to the following debtors:

a) organizations and solo entrepreneurs, which code of the main type of activity is indicated in the list of sectors of the Russian economy that are most affected by the worsening of the situation as a result of the spread of a new coronavirus infection, approved by the decree of the Government of the Russian Federation of April 32020 No. 434 "On approval of the list of sectors of the Russian economy that are most affected by the worsening situation as a result of the spread of a new coronavirus infection"

b) organizations included: 
- to the list of system-forming organizations of the Russian economy in accordance with the criteria and procedure determined by the Government Commission to increase the sustainability of the development of the Russian economy;

- to the list of strategic enterprises and strategic joint stock companies, approved by the Decree of the President of the Russian Federation of August 4, 2004 No. 1009 "On approval of the list of strategic enterprises and strategic joint stock companies"; - in the list of strategic organizations, as well as federal executive bodies ensuring the implementation of a unified state policy in the sectors of the economy in which these organizations operate, approved by the order of the Government of the Russian Federation of August 20, 2009 No. 1226-r.

The list of sectors of the Russian economy that are most affected by the deterioration of the situation as a result of the spread of a new coronavirus infection is provided by the Decree of the Government of the Russian Federation of 03.04.2020 No. 434 (as amended on 26.06.2020) and currently includes 12 different areas of activity:

- transport activities;

- culture, organization of leisure and entertainment;

- physical culture and recreation activities and sports;

- activities of travel agencies and other organizations providing services in the field of tourism;

- hotel business;

- public catering;

- activities of organizations of additional education, non-state educational institutions;

- activities for the organization of conferences and exhibitions;

- activities to provide household services to the population (repair, laundry, dry cleaning, hairdressing and beauty salons);

- activities in the field of health care;

- retail trade in non-food products;

- mass media and printed products.

Based on this list, the Federal Tax Service of Russia compiled a list of legal entities and individual entrepreneurs with the right to a moratorium on bankruptcy (in total, the list included almost 1.3 million companies and individual entrepreneurs). The moratorium was conducted for a period of six months, until October 6, 2020.

Moreover, Germany also had a moratorium on bankruptcy. In accordance with the Law of the Federal Republic of Germany on mitigating the consequences of the COVID-19 pandemic, the following measures are established in the civil, bankruptcy and criminal procedure legislation of March 27, 2020:

a) The obligation to file a petition for your own bankruptcy in accordance with $\S 15 \mathrm{a}$ of the Insolvency Regulations and $\S 42$ (2) of the Civil Code is suspended until 30 September 2020. The above does not apply to those cases if the bankruptcy is not 
related to the consequences of the spread of the SARS-CoV-2 virus (COVID-19 pandemic) or if there is no prospect of eliminating the existing insolvency. If the debtor was not insolvent before December 31, 2019, then it is assumed that the bankruptcy is due to the consequences of the COVID-19 pandemic and there is a possibility of eliminating the existing insolvency.

b) Regarding to the applications of creditors on the introduction of the insolvency procedure in the period from March 28, 2020 to June 28, 2020, it is required that the basis for opening the procedure already existed by March 1, 2020.

Thus, in Germany, in contrast to Russia, first of all, a moratorium is introduced on the performance of the obligation by the debtor himself to file an application for declaring him bankrupt. In Russia, the right to file a bankruptcy petition has been suspended by creditors only in relation to some enterprises. We believe that in Russia it is also necessary to introduce additional measures concerning the release of debtors-business entities from the obligation to file an application with the arbitration court for declaring bankrupt in cases where such an obligation is provided for by the Federal Law "On Insolvency (Bankruptcy)". This measure is advisable in relation to entities operating in the areas most affected by the introduction of restrictions due to the threat of the spread of coronavirus infection.

In addition, in Russia, the Federal Tax Service has completely suspended the filing of bankruptcy applications for all categories of debtors from March 16, 2020. According to experts, in connection with the suspension of the Federal Tax Service of filing bankruptcy applications in March, the number of legal entities-bankrupts in the economy turned out to be $15-18 \%$ lower than it could have been before the adoption of these measures. But the specified measure is not fixed in the normative way. We believe that it is necessary to formalize the action of a moratorium on the filing of applications by tax authorities with an arbitration court for declaring business entities as bankrupts for the duration of the moratorium on bankruptcy.

\section{Results}

So, in the course of the study, it was proved that the main factors affecting the possibility of declaring a business entity bankrupt are the entity's financial stability and its solvency. During a pandemic, enterprises, due to the restrictions imposed by the state, become financially unstable, and their insolvency is recognized, and therefore the state must take measures to introduce a moratorium on the bankruptcy of business entities.

In Russia, such measures are to prohibit the initiation of bankruptcy proceedings at the request of creditors in relation to legal entities and individual entrepreneurs who carry out entrepreneurial activities in the industries most affected by the introduction of restrictions due to the threat of the spread of coronavirus infection, as well as in relation to the backbone organizations of the Russian economy, strategic enterprises 
and strategic joint stock companies. Analysis of statistical data shows a decrease in the number of bankruptcies in connection with the introduction of these measures.

In the course of the study, the need to introduce extra measures to prevent bankruptcies of Russian business entities was identified. We believe it is advisable for the Russian legislator to borrow the experience of the Federal Republic of Germany, in which a moratorium was introduced on the performance of the obligation by the debtor to file an application for declaring him as a bankrupt. We also consider it necessary to establish a regulatory moratorium on the filing of bankruptcy petitions for business entities by the tax authorities.

\section{Conclusions and Some Policy Implications}

In this article, the methods of studying economic and legal phenomena, the concept and economic and legal prerequisites for declaring a debtor as a bankrupt are investigated. The dynamics of bankruptcy of Russian business structures is investigated, measures of the state aimed at preventing massive bankruptcies of entrepreneurs during a pandemic are considered.

The analysis shows that in order to prevent a sharp increase in the bankruptcy of economic entities during a pandemic, the state should take measures to introduce a moratorium on the bankruptcy of certain categories of debtors - subjects of predatory business most affected by restrictions and self-isolation regime during a pandemic.

The implementation of state policy aimed at preventing mass bankruptcy of business entities during a pandemic directly affects the normal functioning of various sectors of the country's economy and ensuring the stability of the state's economy.

\section{References:}

Aloev, T.B., Aslanova, E.M., Belova, M.T. 2015. Analysis and assessment of bankruptcy risk of credit institutions based on information technology. Electronic scientific journal, 3 (3), 263-267.

Bocharov, V.V. 2018. Absolute indicators of financial stability. Available online: https://www.ippnou.ru/print/009531/

Epifanova, T., Romanenko, N., Mosienko, T., Skvortsova, T., Kupchinskiy, A. 2015. Modernization of Institutional Environment of Entrepreneurship in Russia for Development of Innovation Initiative in Small Business Structures. European Research Studies Journal, 18(3), 137-148.

Forecasts. 2020. Bankruptcy of legal entities in Russia: main trends. Available online: www.forecast.ru/_ARCHIVE/Analitics/PROM/2020/Bnkrpc-1-20.pdf

Glugovskaya, K.A., Skvortsova, T.A. 2018. Legal Regulation of Insolvency (bankruptcy) of individual entrepreneurs in Russia. In: An innovative economy for the modern world, Odessa, Publishing house, Kuprienko S.V., 68-75. 
Grima, S., Dalli Gonzi, R., Thalassinos, I.E. 2020. The Impact of COVID-19 on Malta and its Economy and Sustainable Strategies. Available at SSRN: https://ssrn.com/abstract=3644833 or http://dx.doi.org/10.2139/ssrn.3644833.

Khan, S., Rabbani, R.M., Thalassinos, I.E., Atif, M. 2020. Corona Virus Pandemic Paving Ways to Next Generation of Learning and Teaching: Futuristic Cloud Based Educational Model. Available at SSRN: https://ssrn.com/abstract=3669832.

Korovaeva, E.O. 2011. The concept of financial stability of the enterprise and problems calculating this indicator. Economy and management in the XXI century: development trends, 15, 171-175.

Kovan, S.E., Kochetkov, E.P. 2009. Financial stability of the enterprise and its assessment in preventing the bankruptcy. Economic analysis: theory and practice, 15, 52-59.

Milyutina, L.A. 2017. The financial stability of the enterprise as a key feature of the financial condition. GUU Bulletin, 5, 1-4.

Sergienko, O.V. 2015. Factors of Insolvency of Commercial Organizations in conditions of the modern economy. Human Science Humanities Research, 3 (21), 136-144.

Shatkovskaya, T.V., Epifanova, T.V. 2016. Correlation of Private and Public legal Interests as Theoretical and Scientific and Practical Problem of modern law. Journal of Advanced Research in Law and Economics, 3 (7), 625-643.

Shatkovskaya, T.V., Isayev, I.A., Epifanova, T.V., Ismailov, M.A. 2019. The application of Legal-statistical Method in Analysing Manufacturing Property's institutional Development. International Journal of Economics and Business Administration, 7(S1), 231-242.

Skvortsova, T.A., Glugovskaya, K.A., Troitskaya, Yu.A. 2018. Some issues of insolvency (bankruptcy) of citizens-entrepreneurs and business entities. Science and Education: Economy and Economy; entrepreneurship; law and governance, 7(98), 100-103.

Turbanov, A.V. 2006. Concept of State Corporation "Deposit Insurance Agency" activity as a bankruptcy commissioner. Banking law, 1, 2-8.

Zalogin, V.I. 2010. Banking Law. Moscow, Walters Kluver, 260. 